\title{
Bear Market Mutual Funds: Do they Deliver as Promised?
}

\author{
Richard J. Kish* \\ Lehigh University, 621 Taylor St. Bethlehem, PA 18015.
}

\begin{abstract}
Mutual funds with high bear market ratings are tested over both bear markets and bear corrections to determine if their risk adjusted returns outperform the market, as proxied by the S\&P 500 index. The outcomes are mixed showing outperformance during longer bear markets, but not during short bear markets or bear corrections. Thus, the results are not consistent enough to justify investing in the high rated (A+/A) bear markets funds. Although it might be wise to include some $\mathrm{A}+$ or $\mathrm{A}$ bear market rated funds for diversification during downturns in the market.
\end{abstract}

Keywords: Defensive mutual funds, bear markets.

\section{INTRODUCTION}

Periodically, financial publications analyze mutual fund performance. These outlets range from dailies such as The Wall Street Journal and the Financial Times to weekly and monthly magazines such as Fortune, Money, Kiplinger's, Bloomberg Business Week, Money, and Forbes. We focus on just one of these publications, Forbes, to gauge their advice for a buy and hold investor utilizing defensive funds as part of a diversified portfolio. Annually, Forbes analyzes stock fund performance in up and down markets and then publishes the results in the form of letter grades. It should be noted that there are separate ratings based on returns during both bull and bear markets and this paper focuses on the down-market ratings only. Although this process used by Forbes is an improvement over just analyzing returns over a specific period, there is no adjustment of the risk taken on by the various funds. The analysis behind the Forbes ratings is undertaken over two full cycles of up and down markets, thus there is no specific period when comparing the annual analysis over time. ${ }^{1}$ The ratings are parsed out with $5 \%$ of the grades at the top and bottom (A+ or F); $20 \%$ for the $\mathrm{A}$ and $\mathrm{D}$ categories; and $25 \%$ for the $\mathrm{B}$ and $\mathrm{C}$ categories. Additionally, the most recent bull and bear cycles have a greater impact on the final ranking.

Extreme rating examples include Hennessy Focus Fund (HFCSX) which earned an A+ in both the down and the up markets. Another set of extremes are American Century Equity Income Fund (TWEIX) which earned an A+ in the down market, but an F during the up markets versus Fidelity Select Technology (FSPTX) which earned an F in the down market

*Address correspondence to this author at Lehigh University, 621 Taylor St. Bethlehem, PA 18015; Tel: 610/758-4205; E-mail: rjk7@lehigh.edu

\footnotetext{
${ }^{1}$ The analysis 978 funds buying predominately U.S. stocks with assets of at least $\$ 50$ million. See http://www.forbes.com/sites/baldwin/2014/05/05/forbes-mutual-fundratings-2014/.
}

and an A+ during the upmarket. Not all funds have such extremes, for example, Fidelity Select Medical Delivery (FXHCX) earned an A in the down market and an A+ in the upmarket, while Aegis Value (AVALX) earned an A in the down market versus an $\mathrm{A}+$ in the upmarket. Our concern with the Forbes and similar analysis is the lack of adjustment for the amount of risk undertaken by the portfolio managers. From the website, academia.edu, the review article "Investing in the Face of Uncertainty" stresses the importance of including risk in any return analysis. For example, one of the quotes included in the article reinforces this fact: "The road to long-term investment success runs through risk control more than through aggressiveness. Over a full career, most investors' results will be determined more by how many losers they have, and how bad they are, than by the greatness of their winners. Skillful risk control is the mark of the superior investor."

\section{LITERATURE REVIEW}

Bear market mutual funds are a subset of defensive funds, where a defensive mutual fund is defined as a fund that seeks to remain stable regardless of the business cycle. These funds typically invest in stocks that provide a constant or rising dividend and have stable earnings regardless of the market cycle. For example, Morningstar defines a category of Consumer Defensive Mutual Funds as funds seeking capital appreciation by investing in equity securities engaged in manufacturing, sales, or distribution of consumer staples. Other criteria also include consumer discretionary and healthcare.

This is consistent with Ole-Meiludie, et. al. (2014) and others. For instance, Ole-Meiludie, et. al. (2014) investigates the ability of defensive sectors to provide moderation during both recessions and market crises. Taking risk into consideration through the calculation of betas, the authors were able

\footnotetext{
${ }^{2}$ Howard Marks

(http://www.academia.edu/10278819/3587_RECM_REVIEW_ARTICLES 2013_Investing_in_the_Face_of_Uncertainty_FA_)
} 
to support the non-cyclical performance of the defensive sector during both a period of recession and a period of market crisis within the Johannesburg Stock Exchange (JSE). Their definition of a defensive sector is one that is not sensitive to the market's movements. Daves and Philips (2007) define defensive portfolios as those having a historic beta of less than 1. Levy (1984) defines his defensive sector more conservatively as one that has both it's one- and 12-month betas less than 0.6. His findings show that the length of the horizon when the beta is calculated is critical for both aggressive funds and defensive funds, but not for market funds. Defensive stocks with betas less than one decline significantly the longer the time horizon, while aggressive stocks increase significantly.

Surz (2008) reinforces the need to include risk in any analysis of return. Again without taking risk into account, his findings show that large core funds outperformed value and growth regardless of whether the investment holdings were in small, middle, or large firms. But during the last period of his analysis (2000-2008), Treasury bills outperformed both the bond and equity markets.

In a defensive performance study, Bellehumeur (2008) divides defensive stocks up into six sectors: Big Cap Pharma, Utilities/Pipelines, Food Companies, Food/Drug Retailers, Fast Food Giants, and Household Goods. His limited investigation is to sample each sector to gain some insight into performance during the market correction of 2008. Although there is variability within these sectors with food companies performing the best and Pharma performing the worse, on average the defensive sectors outperformed the market and offered some capital protection.

Novy-Marx (2014b) finds that high profitability, next to large CAP stocks, is the best predictor of low volatility and thus defensive strategies should include high-profit firms. In a similar article Novy-Marx (2014a) focuses on quality investing and how it fits into a defensive strategy. He concludes that focusing on both value investing (i.e., buying cheap stocks) and quality investing (i.e., buying uncommonly productive assets) enhances the defensive strategy. Over both bull and bear markets, Brooks et. al. (2012) show that fund managers in their top performance quartile using market-adjusted returns, produced gains from both stock and sector selection. The bottom three quartiles produced lower and at times negative excess returns due to poor sector and stock selection.

In a study of U.K. stocks, Gwilym, et. al. (2012) tests various equity strategies in both bull and bear markets. By first defining the various value trading strategies (Banz (1981) size; Fama and French (1992) price-to-book; Morgan and Thomas (1998) dividend yield; and Lakonishok et. al. (1994) price-to-cash flow), the authors find the key factor in the overall results is how "market states" are defined. Other findings from this period (1980-2006) within the U.K. market show size effects are prominent during up markets, dividend strategies have a profound effect in down markets, and momentum strategies seem to work in both up and down markets.

Various strategies have been attempted to take advantage of active management styles. Grobys (2012) employs regime- switching to defensive asset allocations in the face of an anticipated bear market. During the author's decade of analysis (1991-2000). Regime switching outperformed a buy and hold stock index model using the DJI 30 and the OMX 30. This was contrasted with Black and Litterman (1992) who used an active strategy based upon a mean-variance framework.

Although Froot and Teo (2008) don't directly explore defensive stocks, their conclusions do focus on style investing including value/growth and industry/sector analysis. Value and specific industries have historically been a part of most defensive strategies. In their analysis, they find evidence of style-level trading by institutional investors suggesting wellcharacterized rotation of funds from one style extreme (e.g. value) towards the opposite extreme (e.g. growth).

Asness et. al. (2000) find value in predicting when to invest in value versus growth. Using the spread in valuation multiples between value and growth portfolios and the spread in expected earnings growth and value portfolios, the authors find that the greater the value spread and the smaller the growth spread, the better their forecast for value versus growth. In a follow-up article Asness et. al. (2014) refutes the myths against momentum strategies, some of which follow defensive and aggressive investing styles. Jacobs and Levy (2014) suggest that investors utilize a wide variety of predictor models versus an approach that focuses on one or a few predictors. Furthermore, they stress that any model used must constantly be updated to have any chance of outperforming the market consistently. This is reinforced by noting that small-cap stocks can outperform large-cap stocks in some investment environments but not in others. This supports the position that defensive stocks cannot always outperform aggressive stocks and vice versa.

From another viewpoint, Hereil, et. al. (2010) studies the persistence of mutual fund performance. Points out that academic research often focuses on fund returns, sometimes adjusted for style and market cap biases similar to what we undertake in our analysis. Using a Markov modeling of fund ratings, they show that the persistence of the performance is inconsistent over various time horizons. Thus, ratings are not necessarily time-homogeneous but that style is crucial when comparing the ratings of mutual funds.

\section{DATA}

Our analysis is undertaken on the 984 Forbes ranked funds containing data within Bloomberg. Our bear market defensive funds are all the funds earning either an $\mathrm{A}+$ or an A rating during down markets. The number of bear market funds ranked $\mathrm{A}+$ and $\mathrm{A}$ varied by test period since some funds started later or went out of existence due to liquidation or acquisition. See Table $\mathbf{1}$ for the number of funds by rating category over the entire test period (January 2, 1987, through December 31, 2020), four bear markets, five bull markets, and twelve bear corrections. Also shown in Table $\mathbf{1}$ is the number and percentage of funds that beat the S\&P 500 index, our market proxy, during each period. This gives a broad indication of the performance of the funds. It should be expected that the bear market funds should outperform the S\&P 500 index during both the bear markets and the bear corrections, but the results are inconclusive. For example, 
during the second bear market, 97 percent of the bear market funds outperform the S\&P 500 index on a strictly total return basis. But only 16 percent during the fourth bear market.
This underperformance may be due to the short duration (33 days) of this bear market.

Table 1. Mean comparisons of A+ and A bear rated funds versus the S\&P500.

\begin{tabular}{|c|c|c|c|c|c|c|c|}
\hline \multirow[b]{2}{*}{ Periods } & \multirow[b]{2}{*}{ Dates } & \multicolumn{3}{|c|}{$\mathbf{A +}$} & \multicolumn{3}{|c|}{$\mathbf{A}$} \\
\hline & & $\%$ & Positive & \# Funds & $\%$ & Positive & \# Funds \\
\hline All-time period & $1 / 02 / 1987-12 / 31 / 2020$ & $15.38 \%$ & 8 & 52 & $2.51 \%$ & 5 & 199 \\
\hline Bear Market (1) & $8 / 25 / 1987-12 / 04 / 1987$ & $75.00 \%$ & 3 & 4 & $90.00 \%$ & 27 & 30 \\
\hline Bear Market (2) & $3 / 24 / 2000-10 / 09 / 2002$ & $97.37 \%$ & 37 & 38 & $98.29 \%$ & 172 & 175 \\
\hline Bear Market (3) & $10 / 09 / 2007-3 / 09 / 2009$ & $35.71 \%$ & 15 & 42 & $28.27 \%$ & 54 & 191 \\
\hline Bear Market (4) & $2 / 19 / 2020-3 / 23 / 2020$ & $16.22 \%$ & 6 & 37 & $14.20 \%$ & 24 & 169 \\
\hline Bull Market (1) & $1 / 02 / 1987-8 / 25 / 1987$ & $25.00 \%$ & 1 & 4 & $3.33 \%$ & 1 & 30 \\
\hline Bull Market (2) & $12 / 05 / 1987-3 / 24 / 2000$ & $9.38 \%$ & 3 & 32 & $15.92 \%$ & 25 & 157 \\
\hline Bull Market (3) & $10 / 09 / 2002-10 / 09 / 2007$ & $36.59 \%$ & 15 & 41 & $39.89 \%$ & 75 & 188 \\
\hline Bull Market (4) & $3 / 09 / 2009-2 / 19 / 2020$ & $4.35 \%$ & 2 & 46 & $4.52 \%$ & 9 & 199 \\
\hline Bull Market (5) & $3 / 23 / 2020-12 / 31 / 2020$ & $58.14 \%$ & 25 & 43 & $56.80 \%$ & 96 & 169 \\
\hline Bear Correction (1) & $1 / 02 / 1990-1 / 30 / 1990$ & $57.14 \%$ & 4 & 7 & $83.78 \%$ & 31 & 37 \\
\hline Bear Correction (2) & 7/16/1990-10/11/1990 & $50.00 \%$ & 4 & 8 & $75.56 \%$ & 34 & 45 \\
\hline Bear Correction (3) & 10/07/1997-10/27/1997 & $86.36 \%$ & 19 & 22 & $98.36 \%$ & 120 & 122 \\
\hline Bear Correction (4) & 7/17/1998-8/31/1998 & $55.56 \%$ & 15 & 27 & $60.45 \%$ & 81 & 134 \\
\hline Bear Correction (5) & 7/16/1999-10/15/1999 & $38.71 \%$ & 12 & 31 & $48.34 \%$ & 73 & 151 \\
\hline Bear Correction (6) & $11 / 27 / 2002-3 / 11 / 2003$ & $82.50 \%$ & 33 & 40 & $56.82 \%$ & 100 & 176 \\
\hline Bear Correction (7) & $4 / 23 / 2010-7 / 02 / 2010$ & $58.14 \%$ & 25 & 43 & $48.98 \%$ & 96 & 196 \\
\hline Bear Correction (8) & $4 / 29 / 2011-10 / 03 / 2011$ & $20.45 \%$ & 9 & 44 & $27.92 \%$ & 55 & 197 \\
\hline Bear Correction (9) & $5 / 21 / 2015-8 / 25 / 2015$ & $64.44 \%$ & 29 & 45 & $51.01 \%$ & 101 & 198 \\
\hline Bear Correction (10) & $11 / 03 / 2015-2 / 11 / 2016$ & $6.98 \%$ & 3 & 43 & $8.76 \%$ & 17 & 194 \\
\hline Bear Correction (11) & $1 / 26 / 2018-2 / 08 / 2018$ & $78.57 \%$ & 33 & 42 & $67.80 \%$ & 120 & 177 \\
\hline Bear Correction (12) & $9 / 20 / 2018-12 / 24 / 2018$ & $15.00 \%$ & 6 & 40 & $12.07 \%$ & 21 & 174 \\
\hline
\end{tabular}

Note: If return(bear fund) $>$ return(S\&P500) then positive count. Bold is used to highlight the high and low percentages within each type of market.

Since the S\&P 500 index is utilized as our comparison fund, the returns for the S\&P 500 index over the total, the four bear, and the five bull markets are summarized in Table 2. Returns are recorded as a total return for the period, the annualized return average, and the daily return average for both price appreciation (price change) and the more realistic returns calculated with dividends reinvested back into the index. Both types of returns for twelve bear correction market periods for the S\&P500 are shown in Table 3. These two tables illustrate the variability of the equity markets over time. A bear market is defined as a prolonged market period in which an investment in the S\&P 500 index shows cumulative declines of $20 \%$ or more. A bull market is defined as a prolonged market period in which an investment in the S\&P 500 index shows a cumulative increase of $20 \%$ or more. The bear correction is less severe than a bear market with cumulative declines falling between $10 \%$ and $20 \%$. The returns are shown without and with dividends reinvested into the index to highlight the effect of dividend income over time.
For instance, during the second bear market $(3 / 24 / 2000$ $10 / 09 / 2002)$, the total returns with and without the investment of dividends were $-49.15 \%$ and $-47.38 \%$ respectively. ${ }^{3}$ The annualized and daily returns for the same period were $23.33 \% /-22.29 \%$ and $-0.0529 \% /-0.0510 \%$ without and with dividends reinvested respectively. For the analysis of the mutual funds, dividends received were assumed to be reinvested into the fund. Bull, bear, and bear correction market dates are defined in Tables $\mathbf{1}, \mathbf{2}$, and $\mathbf{3}$.

In the analysis bear market funds are funds rated $\mathrm{A}+$ or $\mathrm{A}$ in the down market periods versus bull or aggressive funds which are rated $\mathrm{A}+$ or $\mathrm{A}$ in the upmarket periods as identified by Forbes. An example of a fund that is rated A+ in both the down and up markets is Hennessy Focus Fund (HFCSX). It is one of the two funds with this designation. It is an open-

\footnotetext{
${ }^{3}$ All return values were obtained from Bloomberg.
} 
ended fund incorporated in the USA. The fund's stated objective is capital appreciation and invests primarily in securities of companies traded in the domestic markets. Its holding on January 25, 2021, was $85.47 \%$ in the U.S., 9.91\% in Canada, and $4.60 \%$ in the U.K. Its top two holdings were O'Reilly Automotive and Brookfield Asset Management. Its return over the past 10 years compared with the Index and its peers were (Firm/Index/Peer/Percentile): 2020 (5.49\%/20.88/14.33 124), 2019 (34.86\%/31.01/27.52/87), 2018 (10.47\%/-5.25/7.24/20), 2017 (19.26\%/21.12/18.39/50), 2016 (7.16\%/12.72 /10.52/24), $2015 \quad(2.88 \% / 0.47 /-1.59 / 80), \quad 2014 \quad(10.20 \% /$ $12.55 / 9.68 / 42), \quad 2013 \quad(35.33 \% / 33.57 / 29.60 / 76), \quad 2012$ (16.64\%/16.42/14.4571), and 2011 (3.63\%/1.03/-2.00/80). All of its return was from capital appreciation. The other fund rated $\mathrm{A}+$ in both the down and up markets is $\mathrm{H} \& \mathrm{~W}$ Small Cap Value-A (HWSAX). Its stated objective is to seek capital appreciation by investing in common stocks of smallcapitalization U.S. companies. The fund seeks stocks whose prospects are misunderstood or not fully recognized by the market. It employs a fundamental value investing approach which seeks to exploit market inefficiencies created by irrational investor behavior. It also invests heavily in the U.S. equity market (79.63\% U.S.; $8.19 \%$ Bermuda; $2.11 \%$ Netherlands; and 0.34\% U.K.). Its largest holdings are in Enstar Group and Euronet Worldwide. Its return over the past 10 years compared with the Index and its peers were (Firm/Index/Peer/Percentile): 2020 (-0.50\%/19.93/4.93/22), $2019 \quad(20.13 \% / 25.49 / 23.33 / 19), \quad 2018 \quad(-15.11 \% /-11.03 /-$ 14.73/47), 2017 (7.47\%/14.63/10.34/23), $2016(19.81 \% /$ 21.28/23.90/18), $2015 \quad(-9.13 \% /-4.41 /-5.67 / 15), \quad 2014$ (11.16\%/4.90/3.65/98), 2013 (45.97\%/38.82/36.91/94), 2012 (23.16\%/16.39/16.14/94), and 2011 (-11.60\%/-4.18/-3.68/4).

Table 2. S\&P 500 Returns by Bear and Bull Market Periods.

\begin{tabular}{|c|c|c|c|c|c|}
\hline & & \multicolumn{4}{|c|}{ S\&P 500 Index (SPX) Return Summary } \\
\hline Total & & & Total & Annual & Daily \\
\hline \multirow[t]{2}{*}{$1 / 02 / 1987-12 / 31 / 2020$} & 1 & Price Change & $1424.07 \%$ & $8.34 \%$ & $0.1147 \%$ \\
\hline & & Div reinvest index & $3139.10 \%$ & $10.76 \%$ & $0.2528 \%$ \\
\hline \multicolumn{6}{|l|}{ Bear } \\
\hline \multirow[t]{2}{*}{ 8/25/1987-12/04/1987 } & 1 & Price Change & $-33.51 \%$ & $-77.12 \%$ & $-0.3318 \%$ \\
\hline & & Div reinvest index & $-32.80 \%$ & $-76.22 \%$ & $-0.3247 \%$ \\
\hline \multirow[t]{2}{*}{$3 / 24 / 2000-10 / 09 / 2002$} & 2 & Price Change & $-49.15 \%$ & $-23.33 \%$ & $-0.0529 \%$ \\
\hline & & Div reinvest index & $-47.38 \%$ & $-22.29 \%$ & $-0.0510 \%$ \\
\hline \multirow[t]{2}{*}{ 10/09/2007-3/09/2009 } & 3 & Price Change & $-56.78 \%$ & $-44.69 \%$ & $-0.1098 \%$ \\
\hline & & Div reinvest index & $-55.22 \%$ & $-43.29 \%$ & $-0.1068 \%$ \\
\hline \multirow[t]{2}{*}{ 2/19/2020-3/23/2020 } & 4 & Price Change & $-33.93 \%$ & $-98.98 \%$ & $-1.0280 \%$ \\
\hline & & Div reinvest index & $-33.79 \%$ & $-98.95 \%$ & $-1.0239 \%$ \\
\hline \multicolumn{6}{|l|}{ Bull } \\
\hline \multirow[t]{2}{*}{ 1/02/1987-8/25/1987 } & 1 & Price Change & $36.65 \%$ & $62.41 \%$ & $0.1560 \%$ \\
\hline & & Div reinvest index & $39.05 \%$ & $66.87 \%$ & $0.1662 \%$ \\
\hline \multirow[t]{2}{*}{$12 / 05 / 1987-3 / 24 / 2000$} & 2 & Price Change & $582.15 \%$ & $16.88 \%$ & $0.1296 \%$ \\
\hline & & Div reinvest index & $841.96 \%$ & $19.98 \%$ & $0.1874 \%$ \\
\hline \multirow[t]{2}{*}{$10 / 09 / 2002-10 / 09 / 2007$} & 3 & Price Change & $1205.00 \%$ & $15.03 \%$ & $0.6599 \%$ \\
\hline & & Div reinvest index & $120.57 \%$ & $17.13 \%$ & $0.0660 \%$ \\
\hline \multirow[t]{2}{*}{ 3/09/2009-2/19/2020 } & 4 & Price Change & $400.52 \%$ & $15.83 \%$ & $0.1002 \%$ \\
\hline & & Div reinvest index & $528.29 \%$ & $18.26 \%$ & $0.1321 \%$ \\
\hline \multirow[t]{2}{*}{$3 / 23 / 2020-12 / 31 / 2020$} & 5 & Price Change & $67.88 \%$ & $95.07 \%$ & $0.2398 \%$ \\
\hline & & Div reinvest index & $70.17 \%$ & $98.51 \%$ & $0.2480 \%$ \\
\hline
\end{tabular}

Note: Bear Market - a prolonged market period with declines of $20 \%$ or more.

Bull Market - a prolonged market period with gains between bear markets of $20 \%$ or more.

Source of S\&P 500 returns: Bloomberg

Source of bull and bear markets timing: Stock Market Briefing: S\&P 500 Bull and Bear Market Tables by E. Yardeni, J. Abbott, and M Quintan, March 23, 2020, Yardeni Research, Inc. (https://www.yardeni.com/pub/sp500corrbeartables.pdf) 
Table 3. S\&P 500 Returns by Bear Corrections.

\begin{tabular}{|c|c|c|c|c|c|}
\hline Bear Correction & & \multicolumn{4}{|c|}{ S\&P 500 Index (SPX) Return Summary } \\
\hline \multirow[t]{2}{*}{ 1/02/1990-1/30/1990 } & 1 & Price Change & $-10.21 \%$ & $-75.42 \%$ & $-0.3645 \%$ \\
\hline & & Div reinvest index & $-10.04 \%$ & $-74.84 \%$ & $-0.3587 \%$ \\
\hline 7/16/1990-10/11/1990 & 2 & Price Change & $-19.92 \%$ & $-60.62 \%$ & $-0.2290 \%$ \\
\hline \multirow[t]{2}{*}{ 10/07/1997-10/27/1997 } & 3 & Price Change & $-10.80 \%$ & $-87.57 \%$ & $-0.5398 \%$ \\
\hline & & Div reinvest index & $-10.75 \%$ & $-87.46 \%$ & $-0.5376 \%$ \\
\hline \multirow[t]{2}{*}{ 7/17/1998-8/31/1998 } & 4 & Price Change & $-19.34 \%$ & $-82.50 \%$ & $-0.4297 \%$ \\
\hline & & Div reinvest index & $-19.19 \%$ & $-82.23 \%$ & $-0.4264 \%$ \\
\hline $11 / 27 / 2002-3 / 11 / 2003$ & & Div reinvest index & $-14.24 \%$ & $-41.68 \%$ & $-0.1369 \%$ \\
\hline \multirow[t]{2}{*}{$4 / 23 / 2010-7 / 02 / 2010$} & 7 & Price Change & $-15.99 \%$ & $-59.70 \%$ & $-0.2285 \%$ \\
\hline & & Div reinvest index & $-15.63 \%$ & $-58.79 \%$ & $-0.2233 \%$ \\
\hline \multirow[t]{2}{*}{ 4/29/2011-10/03/2011 } & 8 & Price Change & $-19.39 \%$ & $-39.41 \%$ & $-0.1235 \%$ \\
\hline & & Div reinvest index & $-18.64 \%$ & $-38.10 \%$ & $-0.1187 \%$ \\
\hline \multirow[t]{2}{*}{$5 / 21 / 2015-8 / 25 / 2015$} & 9 & Price Change & $-12.35 \%$ & $-39.43 \%$ & $-0.1287 \%$ \\
\hline & & Div reinvest index & $-11.89 \%$ & $-38.21 \%$ & $-0.1239 \%$ \\
\hline $11 / 03 / 2015-2 / 11 / 2016$ & 10 & Price Change & $-13.31 \%$ & $-40.62 \%$ & $-0.1331 \%$ \\
\hline
\end{tabular}

Note: Bull Market Correction — a prolonged market period with declines between $10 \%$ and $20 \%$.

Source of S\&P 500 returns: Bloomberg.

Source of bear correction timings: Stock Market Briefing: S\&P 500 Bull and Bear Market Tables by E. Yardeni, J. Abbott, and M Quintan, March 23, 2020, Yardeni Research, Inc. (https://www.yardeni.com/pub/sp500corrbeartables.pdf)

This is contrasted with American Century Equity (TWEIX) which was rate $\mathrm{A}+$ in down markets and $\mathrm{F}$ in up markets. There are 5 funds in this category. Its stated goal is to seek current income with capital appreciation as a secondary objective by investing in securities with a favorable incomepaying history that has prospects for income payments to continue or increase. Its geographical allocation is $76.44 \%$ U.S., 8.28\% Switzerland, $4.93 \%$ Ireland, and 3.30\% U.K. Its largest holdings were Johnson \& Johnson and Medtronic PCL. Its return over the past 10 years compared with the Index and its peers were (Firm/Index/Peer/Percentile): 2020 (1.08\%/2.86/7.17/22), 2019 (24.11\%26.24/25.95/32), 2018 (4.39\%/-8.59/-8.55/84), 2017 (13.33\%/13.17/16.19/22), 2016 (19.49\%18.38/14.07/90), 2015 (0.60\%/-4.14/-3.61/88), 2014 (12.47\%/12.69/8.91/83), 2013 (19.46\%/32.72/31.53/4), 2012 (11.51\%/17.55/15.03/24), and 2011 (3.57\%/-0.10/-0.51/72).
The middle sector of 101 funds rated $\mathrm{C}$ in both the down and up markets is represented by Vanguard Growth \& Income (VQNPX) to provide a total return greater than the return on the Standard \& Poor's 500 Index by investing at least $65 \%$ (and typically 90\%) of its assists in index stocks. Most of the stocks held provide both dividend income and capital appreciation. Its geographic distribution is dominated by U.S. firms $(97.97 \%$ U.S., $1.12 \%$ Ireland, $0.43 \%$ U.K., and $0.30 \%$ Switzerland). Its return over the past 10 years compared with the Index and its peers were (Firm/Index/Peer/Percentile): 2020 (17.94\%/18.40/16.29/58), 2019 (29.66\%/31.49/29.62/ 45), 2018 (-4.71\%/-4.38/-6.01/66), $2017 \quad(20.68 \% / 21.83 /$ 21.74/37), $2016(11.97 \% / 11.96 / 10.08 / 79), 2015 \quad(1.92 \% /$ 1.38/-0.34/74), 2014 (14.04\%/13.69/11.87/83), 2013 (32.59 $\% / 32.39 / 33.48 / 53), 2012(16.92 \% / 16.00 / 16.13 / 70)$, and 2011 $(2.42 \% / 2.11 / 0.40 / 79)$. 
Finally, the only fund rated $\mathrm{F}$ in both the down and up markets is Virtus KAR Capital Growth (PSTAX). Its objective seeks long-term capital growth primarily in stocks of U.S. and foreign companies of any capitalization that the subadvisor believes are well-positioned to benefit from cultural, demographic, regulatory, social, or technological changes worldwide. Its geographical profile shows $86.06 \%$ U.S., 9.8\% China, $2.08 \%$ Argentina, and $1.44 \%$ Ireland. Its top holdings are Amazon and Alibaba Group Holdings. ). Its return over the past 10 years compared with the Index and its peers were (Firm/Index/Peer/Percentile): $2020 \quad(49.47 \% /$ $38.49 / 36.40 / 87), 2019$ (39.69\%/36.39/32.25/96), 2018 (7.77\%/-1.51/-1.87/3), 2017 (35.15\%/30.21/28.58/90), 2016 $(-1.23 \% / 7.07 / 3.27 / 16), \quad 2015 \quad(9.00 \% / 5.67 / 4.52 / 85), \quad 2014$ $(11.38 \% / 13.05 / 10.66 / 58), 2013 \quad(29.09 \% / 33.49 / 34.27 / 10)$, $2012(13.44 \% / 15.26 / 15.55 / 24)$, and $2011(-4.43 \% / 2.64 /-$ $0.79 / 15)$.

\section{ANALYSIS}

The analysis of the returns of the bear market funds over our test period of 1987 through 2020 reveals a wide variation in returns depending on the market. For instance, during the second bear market (3/24/2000-10/9/2002), the monthly return for the S\&P 500 was $-2.08 \%$ versus $-0.18 \%$ and $1.76 \%$ for the $\mathrm{A}+/ \mathrm{A}$ ratings in the defensive (down/bear) and aggressive (up/bull) market funds respectively. The breakdown of the Bull and Bear Market period was obtained from Yardeni Research.i Throughout our analysis, there were 4 bear markets defined as having negative returns of 20 percent or larger and 5 bull markets defined as having positive returns of 20 percent or more.

Looking at only the return of each fund compared to the return of the S\&P500, there are varying periods when the high rated bear funds $(\mathrm{A}+$ and $\mathrm{A})$ were greater than the return of the index. But these results show considerable variation across periods. For instance, over the entire test period, only $15 \%$ of the A+ rate funds show higher returns and only $3 \%$ of the A rated funds. During the four bear markets, the results also show a wide variation. The percentage of $\mathrm{A}+$ bear funds range from a high of $97 \%$ to a low of $16 \%$. The range is even wider for the A-rated bear funds ( $98 \%$ to $14 \%$ ). Dur- ing the bull market periods, the ranges are $58 \%$ to $4 \%$ and $56 \%$ to $3 \%$ for the A+ and A-rated bear funds respectively. The bear corrections periods also show a wide range of results. The ranges are $86 \%$ to $7 \%$ for the A+ rates bear funds and $98 \%$ to $9 \%$ for the A-rated funds. The higher percentages occur during the shorter periods within the bear, bull, and bear correction periods. See Table 1 for a summary of the results.

Three hypotheses are tested within each period using the ttest to account for differences in the means with risk included.

$\mathrm{H}(1)$ : The $\mathrm{A}+$ rated bear funds generate a higher mean return versus the A-rated bear funds adjusted for risk.

$\mathrm{H}(2)$ : The combined $\mathrm{A}+$ and $\mathrm{A}$ bear rated funds generate a higher mean return versus the lower-rated fund when adjusted for risk. Each of the lower-rated funds (B, C, D, and F) are tested individually.

$\mathrm{H}(3)$ : The bear rated funds generate a higher mean return versus the S\&P500 index (our proxy for the market) when adjusted for risk. The $\mathrm{A}+, \mathrm{A}$, and combine $\mathrm{A}+\mathrm{A}$ funds are the focus of this test, although the other rated funds were also tested.

The A+ and A bear market funds are compared to each other to determine if there is a difference in the returns of the two top ratings. Using a t-test, over the total test period, $\mathrm{A}+$ rated bear funds generate a higher mean at a 5\% level of significance. When the means of the combined group of $\mathrm{A}+$ and $\mathrm{A}$ funds are compared to the other lower-rated funds $(\mathrm{B}, \mathrm{C}, \mathrm{D}$, and F) using the standard t-test, the difference was significant at the $1 \%$ level for all 4 lower-rated funds. Finally, comparing the means of the S\&P500 and the combined $\mathrm{A}+/ \mathrm{A}, \mathrm{A}+, \mathrm{A}$, and the other bear rated funds $(\mathrm{B}, \mathrm{C}, \mathrm{D}$, and $\mathrm{F})$, the t-test shows a significant advantage to the top bear rated fund $(\mathrm{A}+)$. The index shows a higher return than the other rated groups. This is expected since the bear rated funds are expected to excel during bear markets, which make up a small portion of the total period. The combined A+/A funds show a significant advantage over the other rated funds.

Table 4. Returns for Bear Ranked Funds.

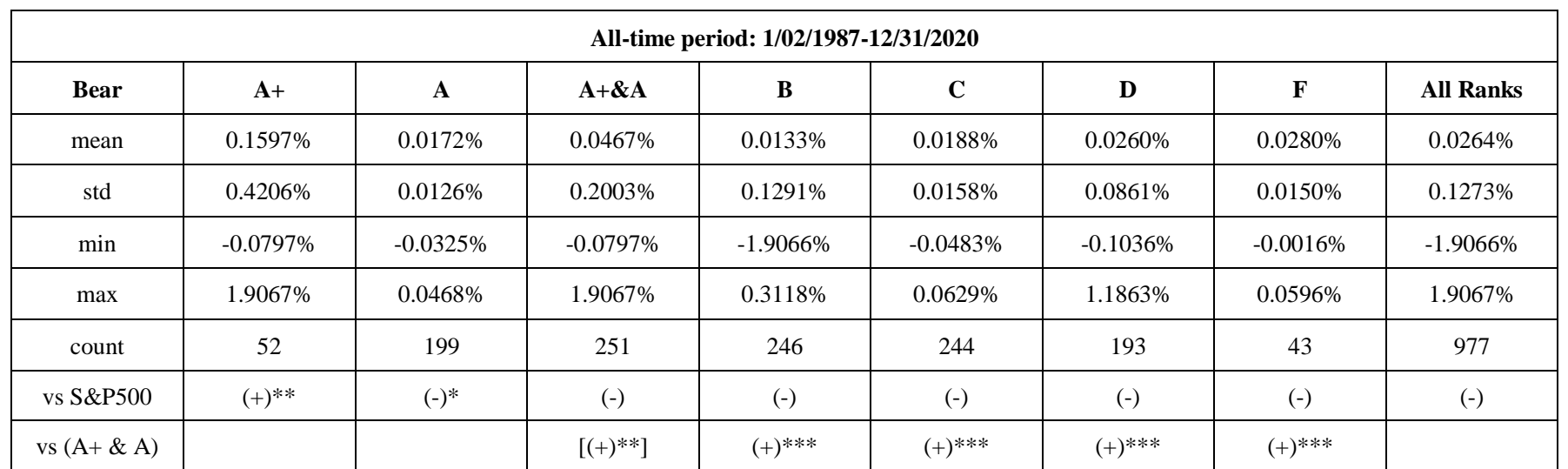

Note: vs S\&P500: Difference of means t-test of the fund category (A+, A, B, C, D, and F) versus the S\&P500. A positive (+) indicates that the bear market fund group outperformed the index. A negative (-) indicates that the index outperformed the bear market fund group.

vs $(A+\& A)$ : Difference of means t-test of the fund categories $[A+v s A]$ and $(B, C, D$, and F) versus the combined category $(A+$ and $A)$. Significance levels for t-test of difference of means: $* * * 1 \%$; $* * 5 \%$, and $* 10 \%$. A positive $(+)$ indicates that the combined category $(\mathrm{A}+$ and $\mathrm{A})$ outperformed the lower-rated bear market fund groups. 
Doing the same comparisons during the four bear market periods the results are mixed. A+ versus A bear market funds show a significant difference at the $1 \%$ level only during the second bear market. Comparing the combined A+/A bear market funds to the other defensive rated funds (ratings B through F) also generate mixed results. During the first bear market, there is a significant difference only with the D $(10 \%)$ and the F (1\%) funds. During the second bear market, there is a $1 \%$ significant difference for all four lower-rated funds. In the third bear period, there is a significant differ- ence favoring the $\mathrm{A}+/ \mathrm{A}$ funds only when compared to the $\mathrm{B}$ (1\%) rated funds. Funds rated C, D, and F all outperformed the $\mathrm{A}+/ \mathrm{A}$ rated funds. Comparisons with the index were insignificant. During the last bear market, the At/A funds were outperformed by the $\mathrm{C}$ and $\mathrm{D}$ rated funds. No funds outperformed the index. Summary statistics for the fund returns during the bear markets are shown in Table 5. Comparing the mean returns of the defensive funds to the S\&P500 are primarily insignificant.

Table 5. Bear Market Returns for Bear Ranked Funds.

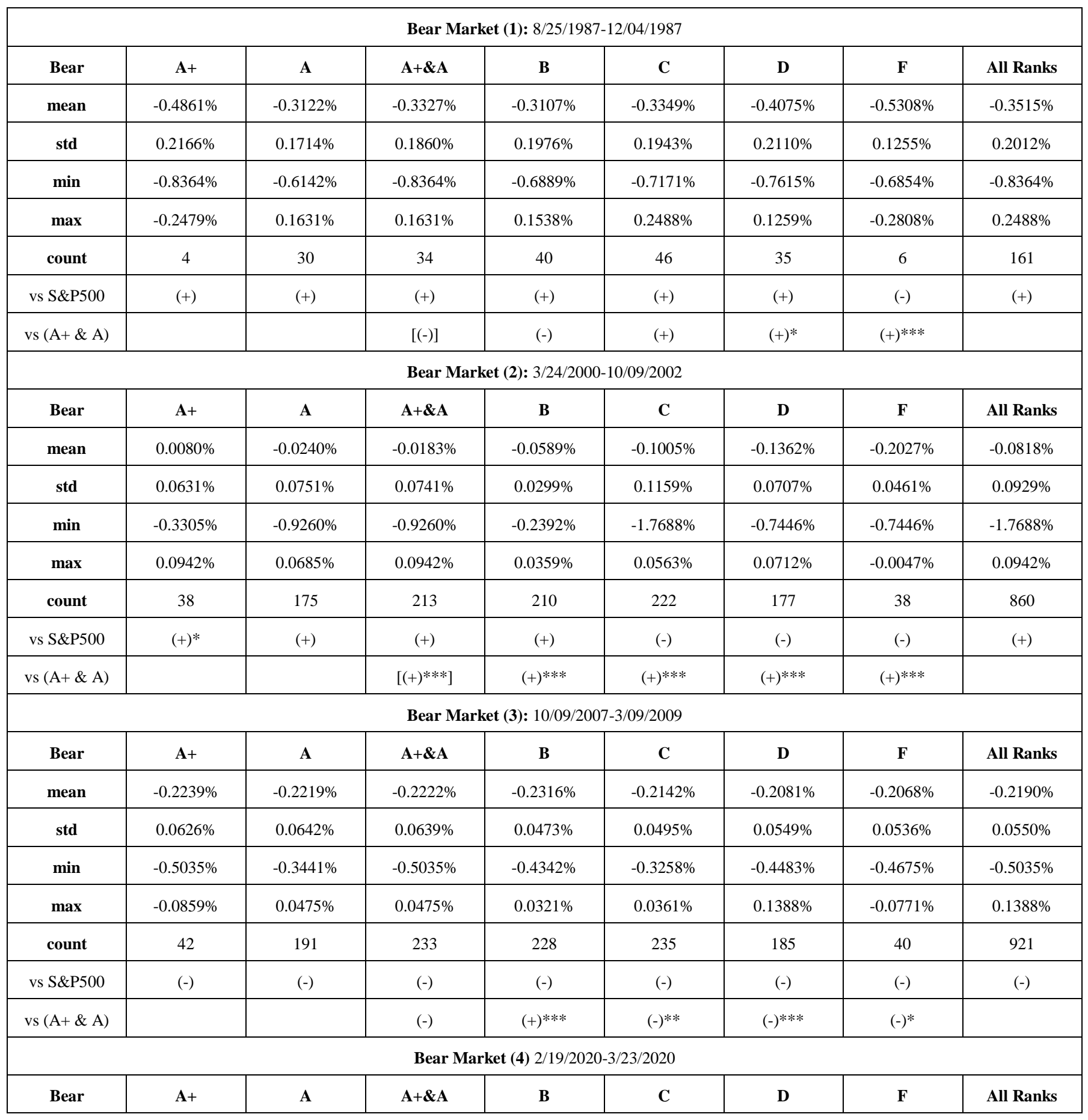




\begin{tabular}{|c|c|c|c|c|c|c|c|c|}
\hline mean & $-1.9153 \%$ & $-1.8969 \%$ & $-1.9002 \%$ & $-1.8888 \%$ & $-1.6474 \%$ & $-1.5113 \%$ & $-2.2518 \%$ & $-1.7779 \%$ \\
\hline std & $0.3852 \%$ & $0.4660 \%$ & $0.4526 \%$ & $0.7896 \%$ & $0.2635 \%$ & $0.3713 \%$ & $4.0201 \%$ & $0.9987 \%$ \\
\hline min & $-3.0276 \%$ & $-2.9029 \%$ & $-3.0276 \%$ & $-10.3960 \%$ & $-2.4770 \%$ & $-2.7337 \%$ & $-25.2918 \%$ & $-25.2918 \%$ \\
\hline max & $-1.0776 \%$ & $0.1608 \%$ & $0.1608 \%$ & $0.1583 \%$ & $-0.0543 \%$ & $0.3702 \%$ & $0.3702 \%$ & $0.3702 \%$ \\
\hline count & 37 & 169 & 206 & 201 & 195 & 143 & 34 & 779 \\
\hline vs S\&P500 & $(-)$ & $(-)$ & $(-)$ & $(-)$ & $(-)$ & $(-)$ & $(-)$ & $(-)$ \\
\hline vs (A+\& A) & & & $(-)$ & $(-)$ & $(-) * * *$ & $(-) * * *$ & $(+)$ & \\
\hline
\end{tabular}

Note: vs S\&P500: Difference of means t-test of the fund category (A+, A, B, C, D, and F) versus the S\&P500. A positive (+) indicates that the bear market fund group outperformed the index. A negative (-) indicates that the index outperformed the bear market fund group.

vs $(A+\& A)$ : Difference of means t-test of the fund categories $[A+v s A]$ and $(B, C, D$, and F) versus the combined category $(A+$ and $A)$. Significance levels for t-test of difference of means: *** $1 \% ; * * 5 \%$, and $* 10 \%$. A positive (+) indicates that the combined category (A+ and A) outperformed the lower-rated bear market fund groups.

Table 6. Bull Market Returns for Bear Ranked Funds.

\begin{tabular}{|c|c|c|c|c|c|c|c|c|}
\hline \multicolumn{9}{|c|}{ Bull Market (1) 1/02/1987-8/25/1987 } \\
\hline Bear & $A+$ & $\mathbf{A}$ & $\mathbf{A}+\boldsymbol{\&} \mathbf{A}$ & $\mathbf{B}$ & $\mathbf{C}$ & $\mathbf{D}$ & $\mathbf{F}$ & All Ranks \\
\hline mean & $0.1324 \%$ & $0.0760 \%$ & $0.0826 \%$ & $0.1544 \%$ & $0.1034 \%$ & $0.1006 \%$ & $0.1808 \%$ & $0.1139 \%$ \\
\hline std & $0.0461 \%$ & $0.0566 \%$ & $0.0584 \%$ & $0.3317 \%$ & $0.0964 \%$ & $0.1050 \%$ & $0.0715 \%$ & $0.1843 \%$ \\
\hline $\min$ & $0.0917 \%$ & $-0.1302 \%$ & $-0.1302 \%$ & $-0.1851 \%$ & $-0.2020 \%$ & $-0.2079 \%$ & $0.0744 \%$ & $-0.2079 \%$ \\
\hline $\max$ & $0.2083 \%$ & $0.2052 \%$ & $0.2083 \%$ & $2.0949 \%$ & $0.3656 \%$ & $0.2942 \%$ & $0.3034 \%$ & $2.0949 \%$ \\
\hline count & 4 & 30 & 34 & 39 & 44 & 35 & 6 & 158 \\
\hline vs S\&P500 & $(-)$ & $(-)$ & $(-)$ & $(-)$ & $(-)$ & $(-)$ & $(-)$ & $(-)$ \\
\hline vs $(A+\& A)$ & & & {$\left[(+)^{* *}\right]$} & $(-)$ & $(-)$ & $(-)$ & $(-)^{* * *}$ & \\
\hline \multicolumn{9}{|c|}{ Bull Market (2) 12/05/1987-3/24/2000 } \\
\hline Bear & $\mathbf{A +}$ & $\mathbf{A}$ & $\mathbf{A}+\mathbf{\& A}$ & B & $\mathbf{C}$ & $\mathbf{D}$ & $\mathbf{F}$ & All Ranks \\
\hline mean & $0.0116 \%$ & $0.0259 \%$ & $0.0235 \%$ & $0.0609 \%$ & $0.0500 \%$ & $0.1280 \%$ & $0.1589 \%$ & $0.0667 \%$ \\
\hline std & $0.0487 \%$ & $0.0907 \%$ & $0.0852 \%$ & $0.1044 \%$ & $0.3192 \%$ & $0.2785 \%$ & $0.1246 \%$ & $0.2214 \%$ \\
\hline $\min$ & $-0.1424 \%$ & $-0.9950 \%$ & $-0.9950 \%$ & $-0.2607 \%$ & $-4.4074 \%$ & $-0.0113 \%$ & $0.0396 \%$ & $-4.4074 \%$ \\
\hline $\max$ & $0.0914 \%$ & $0.1585 \%$ & $0.1585 \%$ & $0.7849 \%$ & $0.3365 \%$ & $3.2546 \%$ & $0.6384 \%$ & $3.2546 \%$ \\
\hline count & 32 & 157 & 189 & 192 & 201 & 155 & 34 & 771 \\
\hline vs S\&P500 & $(-)^{* *}$ & $(-)^{* *}$ & $(-)^{* *}$ & $(-)$ & $(-)$ & $(+)^{* * *}$ & $(+)^{* * *}$ & $(+)$ \\
\hline vs $(A+\& A)$ & & & {$[(-)]$} & $(-)^{* * *}$ & $(-)$ & $(-)^{* * *}$ & $(-)^{* * *}$ & \\
\hline \multicolumn{9}{|c|}{ Bull Market (3) 10/09/2002-10/09/2007 } \\
\hline Bear & A+ & A & $\mathbf{A}+\boldsymbol{\&} \mathbf{A}$ & B & C & D & F & All Ranks \\
\hline mean & $0.0531 \%$ & $0.0521 \%$ & $0.0523 \%$ & $0.0559 \%$ & $0.0582 \%$ & $0.0648 \%$ & $0.0782 \%$ & $0.0584 \%$ \\
\hline std & $0.0228 \%$ & $0.0157 \%$ & $0.0172 \%$ & $0.0174 \%$ & $0.0133 \%$ & $0.0163 \%$ & $0.0136 \%$ & $0.0171 \%$ \\
\hline $\min$ & $-0.0028 \%$ & $0.0034 \%$ & $-0.0028 \%$ & $-0.0730 \%$ & $0.0030 \%$ & $-0.0087 \%$ & $0.0530 \%$ & $-0.0730 \%$ \\
\hline $\max$ & $0.1373 \%$ & $0.1018 \%$ & $0.1373 \%$ & $0.1208 \%$ & $0.1074 \%$ & $0.1207 \%$ & $0.0999 \%$ & $0.1373 \%$ \\
\hline count & 41 & 188 & 229 & 227 & 232 & 183 & 40 & 911 \\
\hline vs S\&P500 & $(-)$ & $(-)$ & $(-)$ & $(-)$ & $(+)$ & $(+)$ & $(+)$ & $(+)$ \\
\hline vs $(A+\& A)$ & & & {$[(+)]$} & $(-)^{* * *}$ & $(-)^{* * *}$ & $(-)^{* * *}$ & $(-)^{* * *}$ & \\
\hline
\end{tabular}




\begin{tabular}{|c|c|c|c|c|c|c|c|c|}
\hline \multicolumn{9}{|c|}{ Bull Market (4) 3/09/2009-2/19/2020 } \\
\hline Bear & $\mathbf{A}+$ & $\mathbf{A}$ & $\mathbf{A}+\boldsymbol{\& A}$ & B & $\mathbf{C}$ & D & $\mathbf{F}$ & All Ranks \\
\hline mean & $0.0297 \%$ & $0.0335 \%$ & $0.0328 \%$ & $0.0412 \%$ & $0.0365 \%$ & $0.0364 \%$ & $0.0446 \%$ & $0.0371 \%$ \\
\hline std & $0.0315 \%$ & $0.0227 \%$ & $0.0246 \%$ & $0.1515 \%$ & $0.0258 \%$ & $0.0290 \%$ & $0.0263 \%$ & $0.0797 \%$ \\
\hline $\min$ & $-0.0797 \%$ & $-0.0636 \%$ & $-0.0797 \%$ & $-1.9066 \%$ & $-0.0657 \%$ & $-0.1036 \%$ & $-0.0245 \%$ & $-1.9066 \%$ \\
\hline $\max$ & $0.1270 \%$ & $0.0705 \%$ & $0.1270 \%$ & $0.9554 \%$ & $0.0746 \%$ & $0.0934 \%$ & $0.0903 \%$ & $0.9554 \%$ \\
\hline count & 46 & 199 & 245 & 246 & 244 & 193 & 43 & 971 \\
\hline vs S\&P500 & $(-)$ & $(-)$ & $(-)$ & $(-)$ & $(-)$ & $(-)$ & $(-)$ & $(-)$ \\
\hline vs $(A+\& A)$ & & & {$[(-)]$} & $(-)$ & $(-)^{* *}$ & $(-)^{*}$ & $(-)^{* * * *}$ & \\
\hline \multicolumn{9}{|c|}{ Bull Market (5) 3/23/2020-12/31/2020 } \\
\hline Bear & A+ & $\mathbf{A}$ & $\mathbf{A}+\boldsymbol{\& A}$ & B & C & D & $\mathbf{F}$ & All Ranks \\
\hline mean & $0.3997 \%$ & $0.2570 \%$ & $0.2860 \%$ & $0.1553 \%$ & $0.2350 \%$ & $0.2463 \%$ & $0.3131 \%$ & $0.2339 \%$ \\
\hline std & $0.3814 \%$ & $0.1532 \%$ & $0.2269 \%$ & $0.6840 \%$ & $0.1924 \%$ & $0.2317 \%$ & $0.0813 \%$ & $0.3936 \%$ \\
\hline $\min$ & $0.1350 \%$ & $-0.8573 \%$ & $-0.8573 \%$ & $-7.0181 \%$ & $-1.0050 \%$ & $-1.3340 \%$ & $0.0872 \%$ & $-7.0181 \%$ \\
\hline $\max$ & $1.9067 \%$ & $0.4612 \%$ & $1.9067 \%$ & $0.4560 \%$ & $0.5671 \%$ & $0.6920 \%$ & $0.5280 \%$ & $1.9067 \%$ \\
\hline count & 43 & 169 & 212 & 199 & 195 & 143 & 33 & 782 \\
\hline vs S\&P500 & $(+)$ & $(-)$ & $(+)$ & $(-)$ & $(-)$ & $(-)$ & $(+)$ & $(-)$ \\
\hline vs $(A+\& A)$ & & & {$\left[(+)^{* *}\right]$} & $(+)^{* * * *}$ & $(+)^{* * *}$ & $(+)^{* *}$ & $(-)^{*}$ & \\
\hline
\end{tabular}

Note: vs S\&P500: Difference of means t-test of the fund category (A+, A, B, C, D, and F) versus the S\&P500. A positive (+) indicates that the bear market fund group outperformed the index. A negative (-) indicates that the index outperformed the bear market fund group.

vs $(\mathrm{A}+\& \mathrm{~A})$ : Difference of means t-test of the fund categories $[\mathrm{A}+\mathrm{vs} \mathrm{A}]$ and $(\mathrm{B}, \mathrm{C}, \mathrm{D}$, and $\mathrm{F})$ versus the combined category $(\mathrm{A}+$ and $\mathrm{A})$. Significance levels for t-test of difference of means: $* * * 1 \% ; * * 5 \%$, and $* 10 \%$. A positive $(+)$ indicates that the combined category $(\mathrm{A}+$ and $\mathrm{A})$ outperformed the lower-rated bear market fund groups.

During the bull markets, the A+ funds significantly outperform the A funds only in the first and fifth bull markets. The combined A+/A funds only outperform the lower-rated funds (B, and D during the fifth bull period. The lower-rated funds outperformed the A+/A funds over mixed periods: $F$ versus $\mathrm{A}+/ \mathrm{A}$ during the first bull market; $\mathrm{B}, \mathrm{D}$, and $\mathrm{F}$ during the second bull market; $\mathrm{B}, \mathrm{C}, \mathrm{D}$, and $\mathrm{F}$ during the third bull period; C, D, and F during the fourth bull period; and F during the fifth bull period. When the funds are compared to the S\&P500, the bear rated funds only outperformed the index during the second bull for funds D and F. During the same period, the index is significantly outperforming the A+ and A bear rated funds. Summary statistics for fund performance during the five bull markets are summarized in Table 6 .
Mixed results are also shown in the bear correction periods. A+ funds significantly outperform the A funds only during the sixth bear correction. A significantly bettered the A+ funds during the fifth bear correction. At/A outperforms the lower-rated funds during the third $(\mathrm{C}, \mathrm{D}$, and F), fourth (D and $\mathrm{F}$ ), and sixth (B and $\mathrm{F}$ ) bear corrections. Lower rated funds outperformed the A+/A funds during the fifth $(C, D$, and $F)$, eighth (C and D), ninth (B), tenth (B and C), eleventh (D), and twelfth (B and D) bear corrections. When comparing the funds to the S\&P500 index, all periods show insignificant differences. Summary statistics for the bear corrections are shown in Table 7.

Table 7. Bear Correction Returns for Bear Rated Funds.

\begin{tabular}{|c|c|c|c|c|c|c|c|c|}
\hline \multicolumn{9}{|c|}{ Bear Correction (1) 1/02/1990-1/30/1990 } \\
\hline Bear & $\mathbf{A}+$ & $\mathbf{A}$ & $\mathbf{A}+\boldsymbol{\& A}$ & $\mathbf{B}$ & $\mathbf{C}$ & $\mathbf{D}$ & $\mathbf{F}$ & All Ranks \\
\hline mean & $-0.3111 \%$ & $-0.2262 \%$ & $-0.2397 \%$ & $-0.1836 \%$ & $-0.2180 \%$ & $-0.3245 \%$ & $-0.3140 \%$ & $-0.1862 \%$ \\
\hline std & $0.1628 \%$ & $0.2315 \%$ & $0.2241 \%$ & $0.2841 \%$ & $0.2183 \%$ & $0.6946 \%$ & $0.2554 \%$ & $0.3954 \%$ \\
\hline $\min$ & $-0.4565 \%$ & $-0.8054 \%$ & $-0.8054 \%$ & $-10.3960 \%$ & $-0.7252 \%$ & $-4.8287 \%$ & $-0.8632 \%$ & $-4.8287 \%$ \\
\hline $\max$ & $0.0374 \%$ & $0.4201 \%$ & $0.4201 \%$ & $1.1157 \%$ & $0.7692 \%$ & $0.2867 \%$ & $0.0345 \%$ & $1.1157 \%$ \\
\hline count & 7 & 37 & 44 & 51 & 58 & 46 & 8 & 207 \\
\hline
\end{tabular}




\begin{tabular}{|c|c|c|c|c|c|c|c|c|}
\hline \multicolumn{9}{|c|}{ Bear Correction (2) 7/16/1990-10/11/1990 } \\
\hline Bear & $\mathrm{A}+$ & A & $\mathrm{A}+\& \mathrm{~A}$ & B & $\mathrm{C}$ & $\mathrm{D}$ & $\mathrm{F}$ & All Ranks \\
\hline mean & $-0.3580 \%$ & $-0.2061 \%$ & $-0.2290 \%$ & $-0.1892 \%$ & $-0.2192 \%$ & $-0.1987 \%$ & $-0.2760 \%$ & $-0.2121 \%$ \\
\hline std & $0.1761 \%$ & $0.1905 \%$ & $0.1961 \%$ & $0.1771 \%$ & $0.1740 \%$ & $0.2417 \%$ & $0.3086 \%$ & $0.2051 \%$ \\
\hline $\min$ & $-0.6724 \%$ & $-0.4843 \%$ & $-0.6724 \%$ & $-0.5418 \%$ & $-0.5523 \%$ & $-0.8821 \%$ & $-0.7374 \%$ & $-0.8821 \%$ \\
\hline $\max$ & $-0.1056 \%$ & $0.2229 \%$ & $0.2229 \%$ & $0.2502 \%$ & $0.2016 \%$ & $0.4081 \%$ & $0.2589 \%$ & $0.4081 \%$ \\
\hline count & 8 & 45 & 53 & 55 & 62 & 54 & 10 & 234 \\
\hline \multicolumn{9}{|c|}{ Bear Correction (3) 10/07/1997-10/27/1997 } \\
\hline Bear & $\mathrm{A}+$ & A & $A+\& A$ & B & $\mathrm{C}$ & $\mathrm{D}$ & $\mathrm{F}$ & All Ranks \\
\hline mean & $-0.3533 \%$ & $-0.2797 \%$ & $-0.2910 \%$ & $-0.3140 \%$ & $-0.3613 \%$ & $-0.4030 \%$ & $-0.5136 \%$ & $-0.3488 \%$ \\
\hline std & $0.3470 \%$ & $0.2523 \%$ & $0.2702 \%$ & $0.2328 \%$ & $0.2941 \%$ & $0.2971 \%$ & $0.2802 \%$ & $0.6681 \%$ \\
\hline $\min$ & $-1.3873 \%$ & $-1.0936 \%$ & $-1.3873 \%$ & $-0.9165 \%$ & $-1.7246 \%$ & $-1.1987 \%$ & $-0.9951 \%$ & $-1.7246 \%$ \\
\hline $\max$ & $0.1796 \%$ & $0.6479 \%$ & $0.6479 \%$ & $0.5109 \%$ & $0.7692 \%$ & $0.6292 \%$ & $0.2274 \%$ & $0.7692 \%$ \\
\hline count & 22 & 122 & 144 & 136 & 153 & 130 & 25 & 588 \\
\hline vs $(A+\& A)$ & & & {$[(-)]$} & $(+)$ & $(+)^{* * * *}$ & $(+)^{* * *}$ & $(+)^{* * * *}$ & \\
\hline \multicolumn{9}{|c|}{ Bear Correction (4) 7/17/1998-8/31/1998 } \\
\hline Bear & A+ & $\mathbf{A}$ & $\mathbf{A}+\boldsymbol{\& A}$ & B & C & D & $\mathbf{F}$ & All Ranks \\
\hline mean & $-0.5554 \%$ & $-0.5547 \%$ & $-0.5548 \%$ & $-0.5661 \%$ & $-0.5554 \%$ & $-0.6267 \%$ & $-0.7984 \%$ & $-0.5830 \%$ \\
\hline std & $0.3426 \%$ & $0.2765 \%$ & $0.2886 \%$ & $0.2746 \%$ & $0.3055 \%$ & $0.3181 \%$ & $0.2145 \%$ & $0.2984 \%$ \\
\hline $\min$ & $-1.1264 \%$ & $-1.1138 \%$ & $-1.1264 \%$ & $-1.0731 \%$ & $-1.2543 \%$ & $-1.4088 \%$ & $-1.1487 \%$ & $-1.4088 \%$ \\
\hline $\max$ & $0.3565 \%$ & $0.4662 \%$ & $0.4662 \%$ & $0.3403 \%$ & $0.6951 \%$ & $0.5170 \%$ & $-0.2007 \%$ & $0.6951 \%$ \\
\hline count & 27 & 134 & 161 & 157 & 170 & 138 & 27 & 653 \\
\hline vs $(A+\& A)$ & & & {$[(-)]$} & $(+)$ & $(+)$ & $(+)^{* * *}$ & $(+) * * *$ & \\
\hline \multicolumn{9}{|c|}{ Bear Correction (5) 7/16/1999-10/15/1999 } \\
\hline Bear & $\mathrm{A}+$ & A & $A+\& A$ & B & $\mathrm{C}$ & $\mathrm{D}$ & F & All Ranks \\
\hline mean & $-0.2023 \%$ & $-0.1691 \%$ & $-0.1748 \%$ & $-0.1793 \%$ & $-0.1259 \%$ & $-0.0833 \%$ & $-0.0265 \%$ & $-0.1382 \%$ \\
\hline std & $0.0960 \%$ & $0.1172 \%$ & $0.1146 \%$ & $0.1075 \%$ & $0.1209 \%$ & $0.1851 \%$ & $0.1502 \%$ & $0.1403 \%$ \\
\hline $\min$ & $-0.3679 \%$ & $-0.5564 \%$ & $-0.5564 \%$ & $-0.5239 \%$ & $-0.4913 \%$ & $-0.4034 \%$ & $-0.2679 \%$ & $-0.5564 \%$ \\
\hline $\max$ & $0.1296 \%$ & $0.4327 \%$ & $0.4327 \%$ & $0.2691 \%$ & $0.3786 \%$ & $1.4850 \%$ & $0.5710 \%$ & $1.4850 \%$ \\
\hline count & 31 & 151 & 182 & 180 & 196 & 147 & 32 & 737 \\
\hline vs $(\mathrm{A}+\& \mathrm{~A})$ & & & {$\left[(-)^{*}\right]$} & & $(-)^{* * *}$ & $(-)^{* * *}$ & $(-)^{* * *}$ & \\
\hline \multicolumn{9}{|c|}{ Bear Correction (6) 11/27/2002-3/11/2003 } \\
\hline Bear & $\mathrm{A}+$ & A & $\mathrm{A}+\& \mathrm{~A}$ & B & $\mathrm{C}$ & $\mathrm{D}$ & $\mathrm{F}$ & All Ranks \\
\hline mean & $-0.1067 \%$ & $-0.1638 \%$ & $-0.1532 \%$ & $-0.1628 \%$ & $-0.1607 \%$ & $-0.1641 \%$ & $-0.1815 \%$ & $-0.1610 \%$ \\
\hline std & $0.1921 \%$ & $0.0778 \%$ & $0.1107 \%$ & $0.0749 \%$ & $0.0711 \%$ & $0.0920 \%$ & $0.0646 \%$ & $0.0876 \%$ \\
\hline $\min$ & $-0.3335 \%$ & $-0.3734 \%$ & $-0.3734 \%$ & $-0.3797 \%$ & $-0.4809 \%$ & $-0.3392 \%$ & $-0.3043 \%$ & $-0.4809 \%$ \\
\hline $\max$ & $0.9469 \%$ & $0.2086 \%$ & $0.9469 \%$ & $0.3216 \%$ & $0.2294 \%$ & $0.3883 \%$ & $0.0504 \%$ & $0.9469 \%$ \\
\hline count & 40 & 176 & 216 & 213 & 223 & 180 & 38 & 870 \\
\hline vs $(A+\& A)$ & & & {$\left[(+)^{*}\right]$} & $(+)^{*}$ & $(+)$ & $(+)$ & $(+) * * *$ & \\
\hline \multicolumn{9}{|c|}{ Bear Correction (7) 4/23/2010-7/02/2010 } \\
\hline Bear & $A+$ & $\mathbf{A}$ & $\mathbf{A}+\boldsymbol{\& A}$ & B & $\mathrm{C}$ & $\mathbf{D}$ & $\mathbf{F}$ & All Ranks \\
\hline mean & $-0.2871 \%$ & $-0.3137 \%$ & $-0.3089 \%$ & $-0.3162 \%$ & $-0.3064 \%$ & $-0.3002 \%$ & $-0.2948 \%$ & $-0.3077 \%$ \\
\hline
\end{tabular}




\begin{tabular}{|c|c|c|c|c|c|c|c|c|}
\hline std & $0.0928 \%$ & $0.1016 \%$ & $0.1006 \%$ & $0.0730 \%$ & $0.0908 \%$ & $0.0834 \%$ & $0.1027 \%$ & $0.0887 \%$ \\
\hline $\min$ & $-0.4796 \%$ & $-1.2048 \%$ & $-1.2048 \%$ & $-0.4774 \%$ & $-0.4704 \%$ & $-0.4847 \%$ & $-0.5722 \%$ & $-1.2048 \%$ \\
\hline $\max$ & $0.0245 \%$ & $0.0915 \%$ & $0.0915 \%$ & $0.2360 \%$ & $0.2872 \%$ & $0.1836 \%$ & $0.1229 \%$ & $0.2872 \%$ \\
\hline count & 43 & 196 & 239 & 234 & 237 & 193 & 43 & 946 \\
\hline \multicolumn{9}{|c|}{ Bear Correction (8) 4/29/2011-10/03/2011 } \\
\hline Bear & $\mathrm{A}+$ & A & $\mathrm{A}+\& \mathrm{~A}$ & B & $\mathrm{C}$ & $\mathrm{D}$ & $\mathrm{F}$ & All Ranks \\
\hline mean & $-0.2204 \%$ & $-0.2162 \%$ & $-0.2170 \%$ & $-0.2158 \%$ & $-0.1984 \%$ & $-0.1934 \%$ & $-0.2123 \%$ & $-0.2070 \%$ \\
\hline std & $0.0732 \%$ & $0.0791 \%$ & $0.0781 \%$ & $0.0699 \%$ & $0.0725 \%$ & $0.0599 \%$ & $0.0791 \%$ & $0.0720 \%$ \\
\hline $\min$ & $-0.3542 \%$ & $-0.3587 \%$ & $-0.3587 \%$ & $-0.3934 \%$ & $-0.3493 \%$ & $-0.3508 \%$ & $-0.4754 \%$ & $-0.4754 \%$ \\
\hline $\max$ & $-0.0018 \%$ & $0.1669 \%$ & $0.1669 \%$ & $0.2141 \%$ & $0.2914 \%$ & $0.0389 \%$ & $0.0051 \%$ & $0.2914 \%$ \\
\hline count & 44 & 197 & 241 & 234 & 240 & 193 & 43 & 951 \\
\hline vs $(A+\& A)$ & & & {$[(-)]$} & $(-)$ & $(-)^{* * *}$ & $(-)^{* * *}$ & $(-)$ & \\
\hline \multicolumn{9}{|c|}{ Bear Correction (9) 5/21/2015-8/25/2015 } \\
\hline Bear & $\mathrm{A}+$ & A & $\mathrm{A}+\& \mathrm{~A}$ & B & $\mathrm{C}$ & $\mathrm{D}$ & F & All Ranks \\
\hline mean & $-0.2683 \%$ & $-0.2063 \%$ & $-0.2178 \%$ & $0.2897 \%$ & $-0.2108 \%$ & $-0.1814 \%$ & $-0.8309 \%$ & $-0.1072 \%$ \\
\hline std & $0.6418 \%$ & $0.2897 \%$ & $0.3811 \%$ & $3.3560 \%$ & $0.3424 \%$ & $0.3170 \%$ & $3.8080 \%$ & $1.9128 \%$ \\
\hline $\min$ & $-4.4965 \%$ & $-4.1483 \%$ & $-4.4965 \%$ & $-3.4159 \%$ & $-4.5374 \%$ & $-4.4972 \%$ & $-25.1467 \%$ & $-25.1467 \%$ \\
\hline $\max$ & $0.1080 \%$ & $0.1006 \%$ & $0.1080 \%$ & $37.5981 \%$ & $0.0589 \%$ & $0.1148 \%$ & $0.0175 \%$ & $37.5981 \%$ \\
\hline count & 45 & 198 & 243 & 246 & 244 & 193 & 43 & 969 \\
\hline vs $(A+\& A)$ & & & {$[(-)]$} & $(-)^{* *}$ & $(-)$ & $(-)$ & $(-)$ & \\
\hline \multicolumn{9}{|c|}{ Bear Correction (10) 11/03/2015-2/11/2016 } \\
\hline Bear & A+ & $\mathbf{A}$ & $\mathbf{A}+\boldsymbol{\& A}$ & B & $\mathbf{C}$ & $\mathbf{D}$ & $\mathbf{F}$ & All Ranks \\
\hline mean & $-0.3439 \%$ & $-0.4250 \%$ & $-0.4103 \%$ & $-0.3433 \%$ & $-0.3434 \%$ & $-0.4372 \%$ & $-0.3812 \%$ & $-0.3809 \%$ \\
\hline std & $0.1774 \%$ & $0.8880 \%$ & $0.8075 \%$ & $0.1472 \%$ & $0.3317 \%$ & $0.8737 \%$ & $0.1314 \%$ & $0.5957 \%$ \\
\hline $\min$ & $-1.0443 \%$ & $-11.4336 \%$ & $-11.4336 \%$ & $-1.7481 \%$ & $-4.9967 \%$ & $-11.4155 \%$ & $-0.7104 \%$ & $-11.4336 \%$ \\
\hline $\max$ & $0.2423 \%$ & $0.1306 \%$ & $0.2423 \%$ & $0.0326 \%$ & $0.1337 \%$ & $0.1229 \%$ & $-0.1730 \%$ & $0.2423 \%$ \\
\hline count & 43 & 194 & 237 & 230 & 238 & 188 & 41 & 934 \\
\hline vs $(A+\& A)$ & & & {$[(-)]$} & $(-)^{* * *}$ & $(-)^{* * *}$ & $(-)$ & $(+)$ & \\
\hline \multicolumn{9}{|c|}{ Bear Correction (11) 1/26/2018-2/08/2018 } \\
\hline Bear & $\mathrm{A}+$ & A & $A+\& A$ & B & $\mathrm{C}$ & $\mathrm{D}$ & F & All Ranks \\
\hline mean & $-0.7787 \%$ & $-0.8626 \%$ & $-0.8465 \%$ & $-1.2167 \%$ & $-1.1102 \%$ & $-0.6711 \%$ & $-0.8291 \%$ & $-0.9735 \%$ \\
\hline std & $0.7567 \%$ & $0.2776 \%$ & $0.4162 \%$ & $3.7059 \%$ & $3.3769 \%$ & $0.2421 \%$ & $0.1187 \%$ & $2.5434 \%$ \\
\hline $\min$ & $-3.4050 \%$ & $-3.6327 \%$ & $-3.6327 \%$ & $-49.5146 \%$ & $-49.5255 \%$ & $-1.3209 \%$ & $-1.1237 \%$ & $-49.5255 \%$ \\
\hline $\max$ & $3.1272 \%$ & $0.0640 \%$ & $3.1272 \%$ & $0.3531 \%$ & $0.3407 \%$ & $0.4372 \%$ & $-0.4911 \%$ & $3.1272 \%$ \\
\hline count & 42 & 177 & 219 & 214 & 207 & 157 & 35 & 832 \\
\hline vs $(A+\& A)$ & & & {$[(+)]$} & $(+)$ & $(+)$ & $(-)^{* * *}$ & $(-)$ & \\
\hline \multicolumn{9}{|c|}{ Bear Correction (12) 9/20/2018-12/24/2018 } \\
\hline Bear & $\mathrm{A}+$ & A & $A+\& A$ & B & $\mathrm{C}$ & $\mathrm{D}$ & $\mathrm{F}$ & All Ranks \\
\hline mean & $-0.5919 \%$ & $-0.5124 \%$ & $-0.5273 \%$ & $-0.4905 \%$ & $-0.4968 \%$ & $-0.4923 \%$ & $-0.4979 \%$ & $-0.5024 \%$ \\
\hline std & $0.5202 \%$ & $0.3180 \%$ & $0.3657 \%$ & $0.2926 \%$ & $0.3290 \%$ & $0.1925 \%$ & $0.1180 \%$ & $0.3032 \%$ \\
\hline $\min$ & $-3.4644 \%$ & $-3.6520 \%$ & $-3.6520 \%$ & $-3.3828 \%$ & $-3.2304 \%$ & $-1.8131 \%$ & $-0.7366 \%$ & $-3.6520 \%$ \\
\hline $\max$ & $-0.0967 \%$ & $0.0533 \%$ & $0.0533 \%$ & $0.0484 \%$ & $0.0366 \%$ & $-0.0393 \%$ & $-0.3056 \%$ & $0.0533 \%$ \\
\hline
\end{tabular}




\begin{tabular}{|c|c|c|c|c|c|c|c|c|}
\hline count & 40 & 174 & 214 & 208 & 204 & 153 & 35 & 814 \\
\hline vs (A+\& A) & & & {$[(-)]$} & $(-)^{*}$ & $(-)$ & $(-)^{* *}$ & $(-)$ & \\
\hline
\end{tabular}

Note: vs S\&P500: Difference of means t-test of the fund category $(A+, A, B, C, D$, and F) versus the S\&P500. All tests insignificant differences. vs $(A+\& A)$ : Difference of means t-test of the fund categories $[A+$ vs A] and $(B, C, D$, and F) versus the combined category $(A+$ and $A)$. Significance levels for t-test of difference of means: *** $1 \% ; * * 5 \%$, and * 10\%. A positive $(+)$ indicates that the combined category $(\mathrm{A}+$ and $\mathrm{A})$ outperformed the lower-rated bear market fund groups. If not recorded insignificance differences.

\section{CONCLUSION}

The total period, the bear markets, the bull markets, and the bear corrections analysis fail to offer support for our three hypotheses. For hypothesis (1), A+ bear market rated funds did outperform A-rated bear market funds, but not consistently. For hypothesis (2), the combined category of A+ and A funds did outperform lower-rated fund classes, but again very inconsistently. Finally, the market proxy, the S\&P 500 index, outperformed the high rated bear market fund categories $(\mathrm{A}+, \mathrm{A}$, and the combined $\mathrm{A}+\mathrm{A})$ consistently. Thus, the three hypotheses are by and large rejected.

During our test period, the results fail to support the benefits of utilizing a buy and hold strategy of bear rated funds. This is primarily due to the short duration of the bear markets and the bear corrections. During the longest bear market (3/24/2000 - 10/09/2002), which lasted 929 days, the A+/A funds dominated the other funds as expected. During this same period, only the A+ funds dominated the S\&P 500 index, offering weak support for the utilization of the top tier bear rated funds. Therefore, although there exist periods when the bear rated funds outperform the lower-rated funds and/or the S\&P500 index, the results are not consistent enough to justify investing in the high rated $(\mathrm{A}+\mathrm{A})$ bear markets funds. Although it might be wise to include some A+ or A bear market rated funds for diversification during downturns in the market.

\section{CONFLICT OF INTEREST STATEMENT}

The authors declare that they have no conflict of interest.

\section{REFERENCES}

Asness, Clifford S., Jacques A. Friedman, Robert J, Krail, and John M. Liew. 2000. Style Timing: Value versus Growth, Journal of Portfolio Management (26:3). 50-60.

Asness, Clifford, Andrea Frazzini, Ronen Israel, and Tobias Moskowitz. 2014. Fact, Fiction, and Momentum Investing. Journal of Portfolio Management (40:5). 75-92.

Banz, Rolf W. 1981. The relationship between return and market value of common stock. Journal of Financial Economics (9:1). 3-18.
Bellehumeur, Larry. 2008. How have 'Traditional Defensive Stocks' done in this downturn. http://seekingalpha.com/article/90129-how-havetraditional-defensive-stocks-done-in-this-downturn.

Black, Fisher and Robert Litterman. 1992. Global portfolio optimization. Financial Analysts Journal (48:5). 28-43.

Brooks, LeRoy D., and Gary E. Porter. 2012. Mutual fund performance attribution: 1994 - 2005. Financial Services Review (21). 259-273.

Davis, J. and C. Phillips. 2007. Defensive equity investing: Appealing theory, disappointing reality. Vanguard Investment Counseling and Research. 1-13.

Fama, Eugene F. and Kenneth R. French. 1992. The cross-section of expected returns. Journal of Finance (47:2). 427-465.

Froot, Kenneth and Melvyn Teo. 2008. Style investing and institutional investors. Journal of Financial and Quantitative Analysis (43:4). 883-906.

Grobys, Klaus. 2012. Active portfolio management in the presence of regime switching: What are the benefits of defensive asset allocation strategies if the investor faces bear markets? Review of Finance and Banking (4:1). 15-31.

Gwilym, Owain Ap, Andrew Clare, James Seaton, and Stephen Thomas. (2012) Tactical equity investing across bull and bear markets. Journal of Wealth Management (Spring). 61-69.

Hereil, Pierre, Philippe Mitaine, Nicolas Moussavi, and Thierry Roncalli. 2010. Mutual Fund Ratings and Performance Persistence (June 25, 2010). Available at SSRN: https://ssrn.com/abstract $=1749414$ or http://dx.doi.org/10.2139/ssrn.1749414

Jacobs, Bruce I. and Kenneth N. Levy. 2014. Ten investment insights that matter. Journal of Portfolio Management (40:5). 60-67.

Lakonishok, Josef, Andre Shleifer, and Robert W. Vishny. 1994. Contrarian Investment, extrapolation, and risk. Journal of Finance (49:5). 1541-1578.

Levy, Haim. 1984. Measuring risk and performance over alternative investment horizons. Financial Analysts Journal (40:2). 61-68.

Morgan, Gareth and Stephen Thomas. 1998. Taxes, dividend yields, and returns in the U.K. equity markets. Journal of Banking and Finance (22:4). 405-423.

Novy-Marx, Robert, 2014a. Quality Investing. Working Paper. Simon Graduate School of Business, University of Rochester http://rnm.simon.rochester.edu/research/QDoVI.pdf

Novy-Marx, Robert, 2014b. Understanding Defensive Equity. Working Paper. Simon Graduate School of Business, University of Rochester http://rnm.simon.rochester.edu/research/UDE.pdf

Ole-Meiludie, Elikanami, Sizwwe Mashinini, Chun-Sung Huang, and Kanshukan Rajaratnam. 2014. A Comparative Study on the Effects of Market Crisis and Recessions on the Performance of Defensive Sectors. The Journal of Applied Business Research. September/October (30:5). 1501-1512.

Surz, Ronald J. 2008. Lessons in Defensive Investing, Journal of Financial Services Professionals. September. 26-30. 